\title{
連層耐震壁を含む骨組の梁理論による近似解析 \\ DEFORMATION ANALYSYS OF A MULTI-STORY BRACED FRAME BY ELEMENTARY BEAM THEORY
}

\author{
柴田道生* \\ Michio SHIBATA
}

\begin{abstract}
Theoretical studies are presented on the elastic behavior of a high-rise building with shear walls using elementary beam thory. The shear wall is modeled to a bar subjected to bending and shearing deformations, and moment resisting frames are approximated as beams subjected to shearing deformations. The shear wall and moment resisting frames are coupled by connecting beams. Deformations are obtained as the solution of ordinary differential equation. The influence of the connecting beam rigidity to the deformation of the system can be investigated by simple tools like the spread-sheet software. The bending deformations of the braced wall of steel structures are reduced by the restraining trusses, so called Hat-Truss or Belt-Truss. Effects of restraining trusses are also investigated.
\end{abstract}

\author{
Keywords : shear wall, bending deformation, shearing deformation, elastic analysis \\ spread sheet software, connecting beam \\ 連層耐震壁, 境界梁, 曲げせん断変形, 弾性解析, 表計算ソフト
}

\section{1 序}

耐震壁は建築骨組の強度・剛性を確保するための有効な手段である が, 多層の連層耐震壁は曲げ変形が卓越して複雑な挙動を示す 1),2). コンピュータおよび解析ソフトの普及はこういった解析を容易な ものとする代償に, 設計行為のブラックボックス化をもたらした. 数值解析結果は, 個々の例題に対する個別の解にすぎず，個々の条 件変数の変動に対する全体的な展望を得るには, 構造物全体を巨視 的に捕まえるアプローチが必要となる.

大型架構の力学的性質を巨視的に把握する試みは, 平面骨組を単 一の壁版に置換する方法 3)や, チューブ構造の大型骨組を薄肉梁に 置換する方法などがあるが 4) 6), コンピュータによる数值解析を 前提としており，耐震壁を含む骨組は対象としていない．

コンピュータが普及する以前は, 境界梁で連結された複合壁体 (cou-pled shear wall) の変形を微分方程式の解として得ようとする試み が Beck $^{7), ~ R o s m a n}{ }^{8)}$, Tso and Chan9) などによってなされ，大沢は同様 の手法が境界梁を持つセンターコア形式骨組にも適用できることを示 した 10). 境界梁については文献 11,12)などの検討があるが，境界梁と それに接続する骨組や壁体との相互作用は近似的に取り扱われている. 日置他は，こうした手法が個々の構成要素の鉛直方向伸縮を考慮 し得ないことを改善するため, 建物全体を反り変形を許容する棒材 に置換する手法を提案し，鉛直方向伸縮の影響が大きいことを指摘 したが，単純な 3 スパン骨組であっても煩雑なマトリクス計算を前
提としており，表計算ソフト程度の解析手段では対応が難しい 13) 本研究は，壁体と骨組が境界梁を介して連結された場合や，いわ ゆるハットトラスあるいはベルトトラスと呼ばれるように，壁体の 頂部または中間部に補剛トラスを設けた系を解析対象とし, 壁体を 曲げせん断棒に，骨組部をせん断棒に置換することにより，多層の 連層耐震壁を含む骨組の, 壁体を含まない構面が混在する場合も含 めた，変形性状を解析的に表現する試みを提示する.

60 年代にほぼ収束したテーマではあるが, コンピュータの普及に よる設計作業のブラックボックス化が進む中，表計算ソフト等の簡 易なツールによって構造物の全体的な傾向を把握することは, なお ざりにされるべきではない.

\section{2 連層壁体単体の挙動}

\section{1 曲げせん断棒モデル}

図 1(a)のトラス置換された壁体を同図(b)のような曲げせん断棒モデ ルで近似すれば，壁体たわみ関数 $v_{w}$ と転倒モーメント $M_{w}$ の関係は

$$
\frac{v_{w}^{\prime \prime}(\zeta)}{H^{2}}=\frac{M_{w}(\zeta)}{K_{b}}-\frac{M_{w}^{n}(\zeta)}{H^{2} K_{s}} \quad \zeta=\frac{z}{H}
$$

ここに，壁体の等価曲げ剛性 $K_{b}$ および等価せん断剛性 $K_{s}$ は

$$
\begin{aligned}
& K_{b}=\frac{1}{2} E A_{w} L_{w}^{2}, \quad K_{s}=2 E A_{d} \sin \theta \cos ^{2} \theta \\
& A_{w} \text { : 壁体側柱断面積, } \quad L_{w} \text { : 壁体スパン } \\
& A_{d} \text { : 壁体斜材断面積, } \quad \theta \text { : 斜材取り付き角 }
\end{aligned}
$$




\section{2 逆三角形分布水平力を受ける単独壁体}

水平荷重分布 $q$ が次式の逆 3 角形分布であれば

$$
q(\zeta)=\left(2 Q_{o} / H\right) \zeta \quad Q_{o}: \text { base shear, } H: \text { 建物高さ }
$$

対応する層せん断力 $Q_{w}$ および転倒モーメント $M_{w}$ は次式となる。

$$
\begin{aligned}
& Q_{w}(\zeta)=Q_{o}\left(1-\zeta^{2}\right) \\
& M_{w}(\zeta)=\frac{2}{3} Q_{o} H\left(1-\frac{3}{2} \zeta+\frac{1}{2} \zeta^{3}\right)
\end{aligned}
$$

壁体脚部では杭の伸縮などによる回転角 $\theta_{b o}$ が生じる

$$
\theta_{b o}=\frac{M_{o}}{K_{w}}, \quad M_{o}=\frac{2}{3} Q_{o} H, \quad K_{w}=\frac{(E A)_{p} L_{w}^{2}}{2 L_{p}}
$$

$L_{p}:$ 杭長, $(E A)_{p}:$ 杭の伸び剛性

壁体剛性が高さ方向に一様の場合, 式(6)を考慮して式(5)を式(1) に代入すれば, たわみ関数 $v(\zeta)$ は

$$
\begin{gathered}
v(\zeta)=\frac{2 Q_{o} H^{3}}{3 K_{b}}\left[\left(\gamma+\frac{3}{2} \beta_{w}\right) \zeta+\frac{1}{2} \zeta^{2}-\frac{1}{2}\left(\frac{1}{2}+\beta_{w}\right) \zeta^{3}+\frac{1}{40} \zeta^{5}\right] \\
\ldots \ldots
\end{gathered}
$$

図 2 (a)は図 3 の 16 層モデルによる数值解析結果と式(7)の比較を 示す. 図中の $k_{w}=K_{w} /\left(K_{S} H\right)$ は壁体脚部の回転剛性と筋違による せん断剛性の比を示し, $k_{w}=\infty$ は壁体脚部が剛な場合に, $k_{w}=0.7$ は断面積 $1 \mathrm{~m}^{2}$, 杭長 $20 \mathrm{~m}$ の場所打ち杭を想定して式(6)より得た $K_{w}$ に対応する.また，印の数值解析結果は式(7)と良好な対応を示す.

\section{3 魚骨骨絈単体の挙動}

\section{1 せん断棒モデル}

図1(c)の骨組を同図(d)のようなせん断棒モデルに置換すれば，た わみ関数 $v_{f}$ と層せん断力 $Q_{f}$ の関係は

$$
\frac{v_{f}^{\prime}(\zeta)}{H}=\frac{Q_{f}(\zeta)}{K_{f}}
$$

ここに, 純骨組部の等価せん断剛性 $K_{f}$ は次式で評価される.

$$
K_{f}=\frac{\mu_{b}}{1+\mu_{b}} \frac{12 E I_{c}}{h^{2}}
$$

$h$ : 標準階高, $I_{c}$ : 骨組部柱断面 2 次モーメント $\mu_{b}=\frac{I_{b} / L}{I_{c} / h}:$ 柱に対する梁の剛比

\section{2 逆三角形分布水平力を受ける魚骨骨組}

式(3)で定義される逆三角形分布水平力を受ける骨組の層せん断 力は式 (4)で与えられ，たわみ関数は次式となる.

$$
v_{f}(\zeta)=\frac{Q_{o} H}{K_{f}} \zeta\left(1-\frac{1}{3} \zeta^{2}\right)
$$

式(10) と数値解の比較を図 2 (b)に示す，図中の実線は式(10)による解 析解を，口印は 16 層骨組に対する数值解を示す．数值解では基礎梁の 剛性を一般階の 10 倍としているので, 第 1 層の層間変位が解析解より 小さく計算されているが，それ以外の層での両者の対応は良好である.

\section{4 トラス壁体と魚骨骨組が単純連結された系}

\section{1 適合条件}

図 1 (a)の壁体と同図(c)の骨組が単純連結された図 5 の系は, 戸境 壁と純骨組が交互に組合わさった集合住宅建築などに類似する.

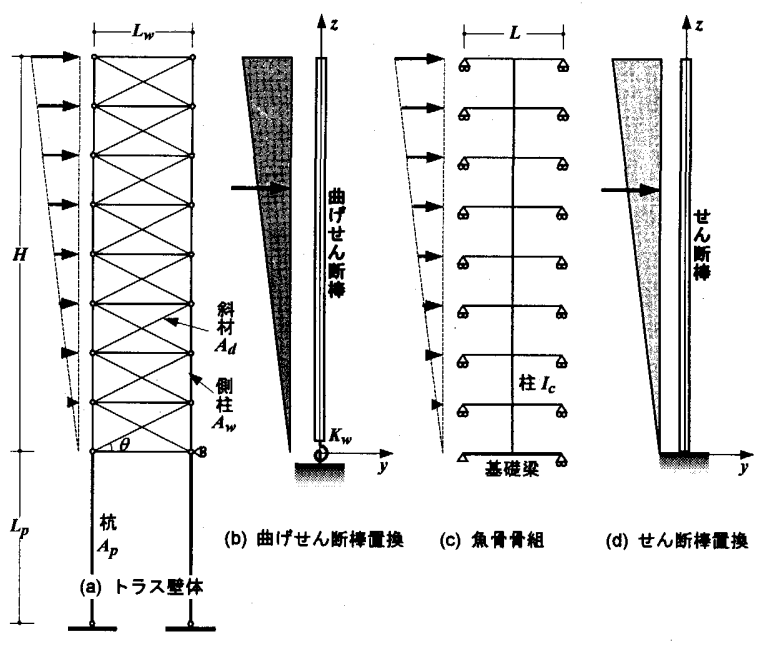

図 1 連層壁体と魚骨骨組

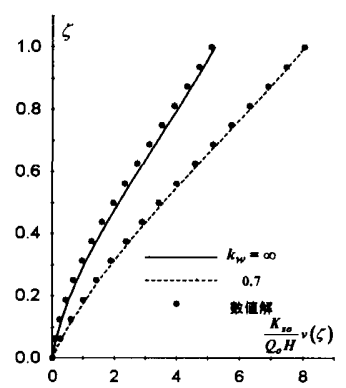

(a) 単独壁体 図 2 変形モート

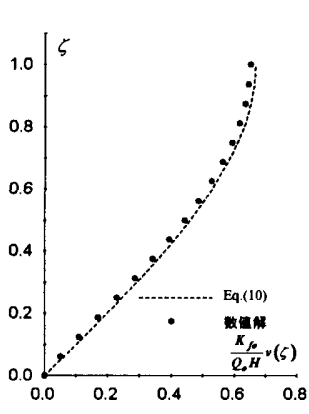

(b) 純骨組

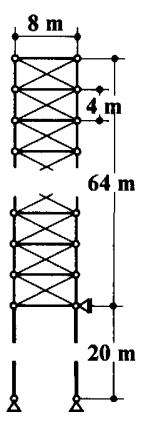

図 3 壁体の数 值解析モデル
この系では，壁体の負担する転倒モーメント $M_{w}$ と骨組部の負担 する層せん断力 $Q_{f}$ の間に, 次の適合条件が成立する.

$$
\frac{v^{\prime \prime}(\zeta)}{H^{2}}=\frac{M_{w}(\zeta)}{K_{b}}-\frac{M_{w}^{\prime \prime}(\zeta)}{H^{2} K_{s}}=\frac{Q_{f}^{\prime}(\zeta)}{H K_{f}}
$$

系全体の転倒モーメントを $M(\zeta)$ と表せば

$$
Q_{f}(\zeta)=-\frac{1}{H} M_{f}^{\prime}(\zeta)=-\frac{1}{H}\left[M^{\prime}(\zeta)-M_{w}^{\prime}(\zeta)\right]
$$

を式(11)に代入して

$$
M_{w}^{\prime \prime}(\zeta)-\frac{K_{s} K_{f}}{K_{s}+K_{f}} \frac{H^{2}}{K_{b}} M_{w}(\zeta)=\frac{K_{s}}{K_{s}+K_{f}} M^{\prime \prime}(\zeta)
$$

\section{2 逆三角形分布水平力を受ける単純連結系}

系が逆三角形分布水平力を受ける場合，式(5)右辺を式(12)右辺に 代入し，系の剛性が高さ方向に一様と仮定すれば，次式を得る.

$$
\begin{aligned}
& M_{w}^{n}(\zeta)-\omega^{2} M_{w}(\zeta)=2 D Q_{o} H \zeta \\
& \quad D=\frac{K_{s}}{K_{s}+K_{f}}, \quad \omega^{2}=\frac{D}{\beta_{f}}, \quad \beta_{f}=\frac{K_{b}}{K_{f} H^{2}}
\end{aligned}
$$

式(13)の一般解

$$
M_{w}(\zeta)=2 Q_{o} H\left[A \sinh (\omega \zeta)+B \cosh (\omega \zeta)-\beta_{f} \zeta\right]
$$

に，境界条件

$$
\begin{aligned}
& M_{w}(1)=0, Q_{f}(0)=Q_{o}-Q_{w}(0)=K_{f} \theta_{o} \\
& \theta_{o}=\frac{M_{w}(0)}{K_{w}}+\frac{Q_{w}(0)}{K_{s}} \quad: \text { 壁体脚部のたわみ角 }
\end{aligned}
$$

を考虑すると, 次の連立方程式の解として積分定数 $A, B$ を得る. $A \sinh (\omega)+B \cosh (\omega)=\beta_{f}$ 


$$
\begin{gathered}
A \frac{\omega}{D}-B \frac{K_{f} H}{K_{w}}=\frac{\beta_{f}}{D}-\frac{1}{2} \\
\text { たわみ曲線は } \frac{v^{\prime}(\zeta)}{H}=\frac{Q_{f}(\zeta)}{K_{f}}=\frac{M_{w}^{\prime}(\zeta)-M^{\prime}(\zeta)}{K_{f} H}+\theta_{o} \\
v(\zeta)=\frac{Q_{o} H}{K_{s}} 2 \frac{\beta_{f}}{\beta_{w}}\left[A \sinh (\omega \zeta)+B \cosh (\omega \zeta)-B+\left(\frac{1}{2}-\beta_{f}\right) \zeta-\frac{1}{6} \zeta^{3}\right]
\end{gathered}
$$

図 4 (a)は 1 組の筋違付き壁体に対して 1 組の魚骨骨組が連結され た Case 1 (図 5 参照) と 4 組の魚骨骨組が連結された Case 4 につい て, 式(18) と数值解析結果の比較を示す. 図中の 1 点鎖線は壁体脚 部の回転剛性が岡な場合，破線は回転を許容した場合で，・印は図 5 のモデルによる数値解である. 骨組部の水平力分担が小さいと, 壁体脚部の回転剛性が変形性状に大きな影響を与えるが，骨組部の 分担が大きくなると相対的に脚部回転剛性の影響は小さくなる.

図 4 (b)は壁体と骨組部の層せん断力の分担を示す. 壁体脚部の回転 剛性の水平力分担率に及ぼす影響は小さい, 骨組部は各層でほぼ等し い層せん断力を分担するのに対し, 壁体部の分担水平力は上層部で激 減し, 最上層部では逆せん断が生じている。これは, 壁体の中・下層 部は耐震要素として機能するが, 最上層部では水平力に抵抗するより もむしろ骨組部にもたれかかっていることを意味する.もたれかかり の度合いは，骨組部の分担せん断力が大きいほど顕著である.

図 4 (b)では壁体部と骨組部には最上層において，大きさが等しく方 向が逆のせん断力が生じている. これは, 解析モデルの最上層つなぎ 材に大きな軸力が発生していることに相当し, 実際の建物では最上層 林レベルでの力のやりとりの検討が必要であることを示す (図6参照).

\section{5 境界梁を介して連結された壁体と骨組}

\section{1 境界梁とそれに隣接する構造要素の性状}

\section{1) 境界梁による拘束}

境界梁の存在により連層壁体の曲げ変形は抑制される.ここでは, 壁体と同一構面内の境界梁のみを取り扱うが，壁体に直交する境界 梁についても同様の考察が適用できる.

系が層間変位角 $R$ の水平変位を生じたとき (図 7 (a) 参照), 境界 梁の節点モーメント $M_{A B}$ およびせん断力 $Q_{A B}$ によって，棒材で近 似された壁体 (同図(b)) は各節点に次のの拘束モーメントを受ける.

$$
M^{\#}=M_{A B}+Q_{A B} \cdot L_{w} / 2
$$

\section{2）壁体のせん断剛性が大きい場合}

鉄筋コンクリート造壁体のように壁体のせん断剛性が大きい場合は, 境界梁 $\mathrm{AB}$ の $\mathrm{A}$ 点でのたわみ角は層間変位角 $R$ に等しい. 図 8 はせん 断剛性の大きい連層壁体と骨組部が境界梁でつながれた架構が，水平 力を受けて変形した状態を示す。この骨組部の効果を図 9 (a)のように 傾斜した回転バネで置換すると, バネの傾き $\theta_{B 0}$ は境界梁を持たない骨 組の節点角に相当し (同図(b)参照), バネの相対回転角 $\theta_{B 1}$ は境界梁の 材端モーメント $M_{B A}$ によって生じた節点角に相当する (同図(c)参照).

$$
\begin{aligned}
& \theta_{B}=\theta_{B 0}-\theta_{B 1}=\frac{2 R}{2+\mu_{2}}-\theta_{B 1} \quad \mu_{2}=\frac{I_{2} / L_{2}}{I_{c} / h} \\
& K_{B}=\frac{M_{B A}}{\theta_{B 1}}=\frac{\left(12+8 \mu_{2}+\mu_{2}^{2}\right) E I_{c}}{\left(1+\mu_{2} / 3\right) h}
\end{aligned}
$$

$L_{2}, I_{2}, I_{c}$ は骨組部のスパンと梁・柱の断面 2 次モーメントである. 式(20)は図 9 (b), (c) に示す 1 スパン骨組について得られたもので

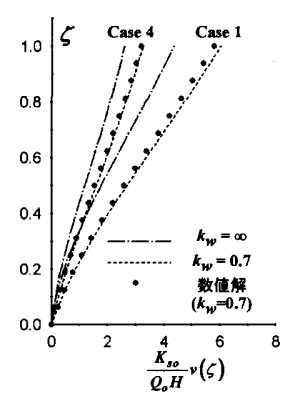

(a) 水平変位

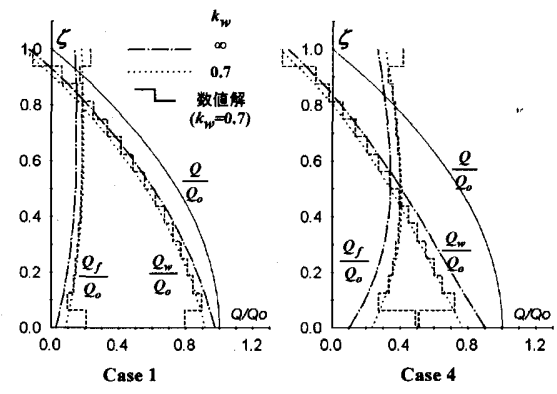

(b) 分担せん断力
図 4 水平変位と分担せん断力
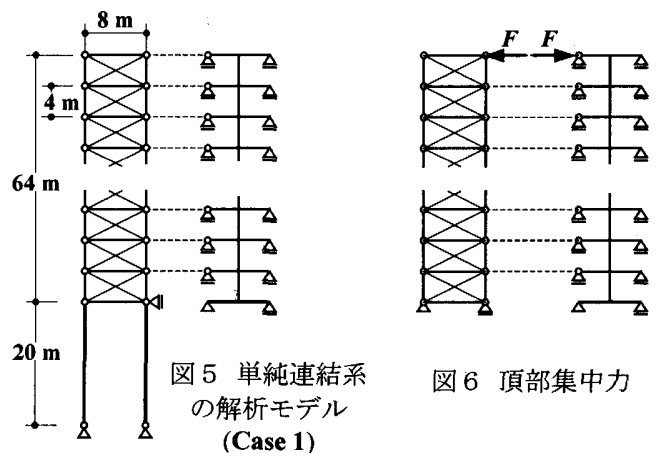

図 6 頂部集中力

あるが，2スパン以上の骨組部に対しても良好な近似を与える。一 方, 骨組部が柱のみで構成される場合は $\mu_{2}=0$ とおいて次式を得る.

$$
\theta_{B O}=R, \quad K_{B}=12 E I_{c} / h \quad(21 \mathrm{a}, \mathrm{b})
$$

また，境界梁の材端モーメント $M_{B A}$ によって骨組部の柱には

$$
Q_{B B^{\prime}}+Q_{C C^{\prime}}=\frac{12 E K_{c}}{h}\left(\theta_{B 1}+\theta_{C 1}\right)=\frac{2 K_{B}}{h\left(2+\mu_{2}\right)} \frac{\theta_{B 1}}{R} R
$$

のせん断力が付加され，骨組部の見かけのせん断剛性は増加する

$$
K_{f}=\frac{2 \mu_{2}}{2+\mu_{2}} \frac{12 E I_{c}}{h^{2}}+\frac{2 K_{B}}{h\left(2+\mu_{2}\right)} \frac{\theta_{B 1}}{R}
$$

\section{3）壁体のせん断剛性が大きくない場合}

鉄骨ブレース付き壁体のように壁体のせん断剛性が大きくない場 合は, 壁体を剛節ラーメンとピン接合された筋違の組み合わせとし てモデル化し, 境界梁の壁体側を図 10 のような傾斜 $\lambda R$ の回転バネ で置換すれば，回転バネの回転剛性は式(20b)と同様に次式で得られ る.ここに入は壁体の曲げ変形角と層間変位角 $R$ の比である.

$$
K_{A}=\frac{M_{A B}}{\theta_{A 1}}=\frac{\left(12+8 \mu_{g w}+\mu_{g w}^{2}\right) E I_{c w}}{\left(1+\mu_{g w} / 3\right) h} \quad \mu_{g w}=\frac{I_{g w} / L_{w}}{I_{c w} / h}
$$

ここに, $I_{g w}, I_{c w}$ は壁体部梁・柱の断面 2 次モーメントである.

$$
\text { 幾何学的条件 } \theta_{A}=\lambda R-\theta_{A 1}, \quad R_{A B}=-\frac{L_{w}}{2 L_{1}} \lambda R
$$

と式(20), および境界条件

$$
\begin{aligned}
& K_{A} \theta_{A 1}=2 E K_{1}\left(2 \theta_{A}+\theta_{B}-3 R_{A B}\right) \\
& K_{B} \theta_{B 1}=2 E K_{1}\left(\theta_{A}+2 \theta_{B}-3 R_{A B}\right)
\end{aligned}
$$

より， $\theta_{A 1}$ および $\theta_{B 1}$ は次式の根として求まり，

$$
\begin{aligned}
& \left(4+\frac{K_{A}}{E K_{1}}\right) \theta_{A 1}+2 \theta_{B 1}=\left[\left(4+3 \frac{L_{w}}{L_{1}}\right) \lambda+\frac{4}{2+\mu_{2}}\right] R \\
& 2 \theta_{A 1}+\left(4+\frac{K_{B}}{E K_{1}}\right) \theta_{B 1}=\left[\left(2+3 \frac{L_{w}}{L_{1}}\right) \lambda+\frac{8}{2+\mu_{2}}\right] R
\end{aligned}
$$

境界梁の壁体に及ぼす効果は次式で評価される. 

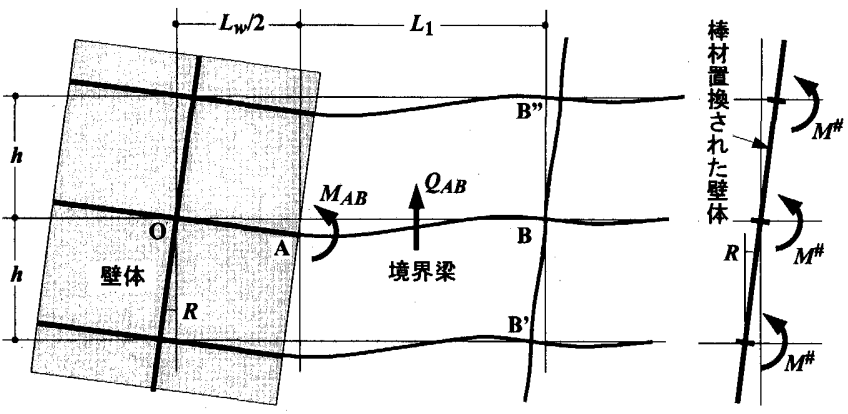

(a) 境界梁による拘束

図 7 境界梁による拘束

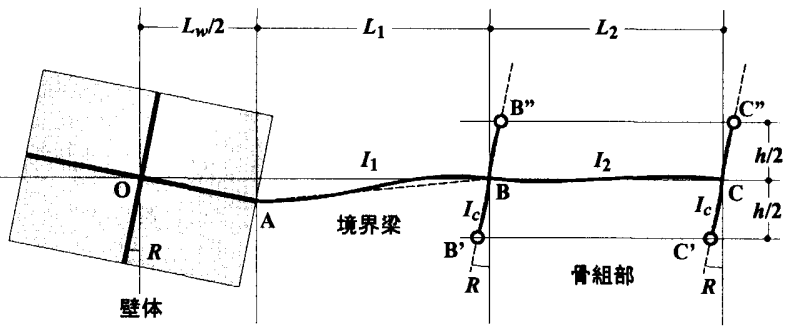

図 8 水平力を受ける壁体と境界梁

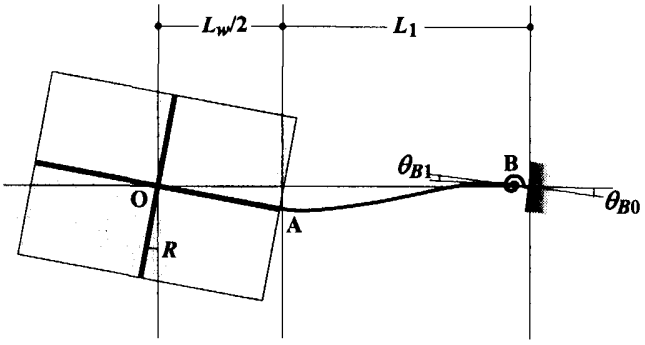

(a)

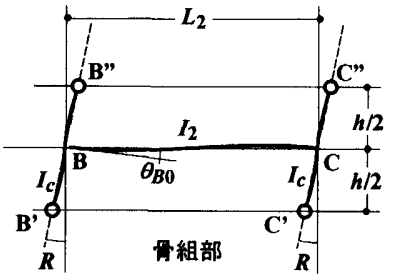

(b)

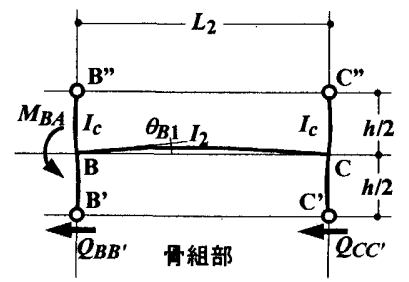

(c)

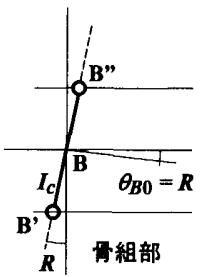

(d)

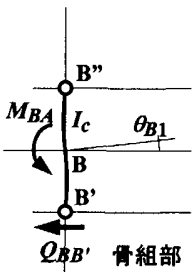

(e)
図 9 境界梁に隣接する骨組のモデル

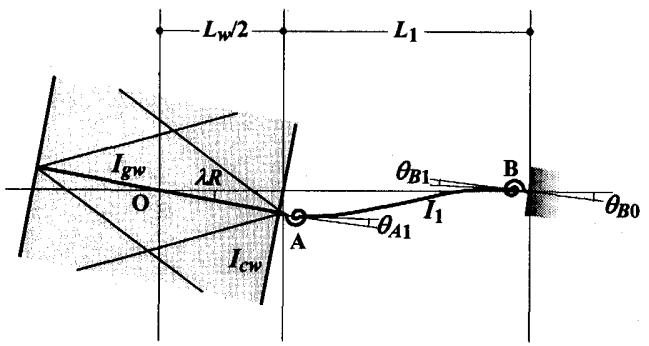

図 10 鉄骨ブレース付き壁体の壁体周り

$$
\begin{aligned}
& M^{\#}=M_{A B}+\frac{M_{A B}+M_{B A}}{L_{1}} \frac{L_{w}}{2}=K_{g} \lambda R \\
& K_{g}=\frac{E K_{c}}{\lambda}\left[\left(1+\frac{L_{w}}{2 L_{1}}\right) \frac{K_{A}}{E K_{c}} \frac{\theta_{A 1}}{R}+\frac{L_{w}}{2 L_{1}} \frac{K_{B}}{E K_{c}} \frac{\theta_{B 1}}{R}\right]
\end{aligned}
$$

また, 壁体のせん断剛性は剛節ラーメンとしての剛性を考慮して,

$$
K_{s}=2 E A_{d} \sin \theta \cos ^{2} \theta+\frac{2 \mu_{g w}}{2+\mu_{g w}} \frac{12 E I_{c w}}{h^{2}}
$$

4) $\lambda$ の評価

壁体の曲げ変形角と層間変位角の比 $\lambda$ は, 鉄筋コンクリート壁体 のように壁体のせん断剛性が大きい場合は $\lambda=1$ と見なせる. しかし ブレース付鉄骨壁体のように，せん断剛性があまり大きくない場合 は, 分担せん断力の大きい下層では小さく, 上層では 1 に近づく. また，境界梁の剛性が大きくなると入は低下する，本解析では，高 さ方向の平均的な $\lambda$ として次式を用いる.

$$
\lambda=K_{s} /\left(K_{s}+k_{g}\right)
$$

ここに, $k_{g}=K_{g} / h$ は単位長さ当たりの境界梁の回転剛性である.

\section{2 境界梁を持つ壁体と骨組が単純連結された系}

\section{1) 壁高に沿って連続の境界梁を持つ壁体}

壁体が壁高に沿って単位長さ当たり $k_{g}$

$=K_{g} / h$ のバネ定数を持つ回転バネで拘束

されている場合，壁体はその曲げ変形

$\theta_{b}(\zeta)=v_{b}^{\prime}(\zeta) / H$ に忍じて単位長さあ

たり $m^{\#}=k_{g} \theta_{b}(\zeta)$ の拘束モーメントを

受け，図11より次式を得る.

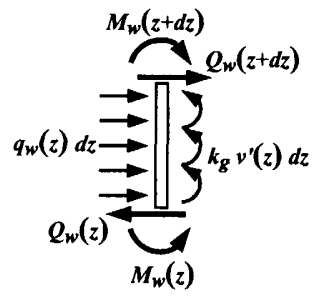

$\frac{v_{b}^{\prime}(\zeta)}{H}=\frac{1}{k_{g}}\left[\frac{M_{w}^{\prime}(\zeta)}{H}+Q_{w}(\zeta)\right]$

（29）図11 材軸に沿って連続的 に回転拘束を受ける棒材

2）境界梁を持つ壁体と魚骨骨組が単純連結された系

壁体の曲げおよびせん断変形は次式で表され，

$$
\frac{v_{b}^{\prime \prime}(\zeta)}{H^{2}}=\frac{M_{w}(\zeta)}{K_{b}}, \quad \frac{v_{s}^{\prime}(\zeta)}{H}=\frac{Q_{w}(\zeta)}{K_{s}}
$$

骨組部のたわみ

$$
\frac{v^{\prime}(\zeta)}{H}=\frac{Q_{f}(\zeta)}{K_{f}}=\frac{Q(\zeta)-Q_{w}(\zeta)}{K_{f}}
$$

と式(29)を考慮することにより次の支配方程式を得る.

$$
M_{w}^{\prime \prime}(\zeta)-\frac{H^{2}}{K_{b}}\left(k_{g}+\frac{K_{s} K_{f}}{K_{s}+K_{f}}\right) M_{w}(\zeta)=\frac{K_{s} H^{2}}{K_{s}+K_{f}} q(\zeta)
$$

3）逆三角形分布水平力を受ける場合

式(3)の逆三角形分布水平力を受ける場合, 式(32)の解は次式となり，

$$
M_{w}(\zeta)=2 Q_{o} H[A \sinh (\omega \zeta)+B \cosh (\omega \zeta)-C \zeta]
$$

$$
\omega^{2}=\frac{H^{2}}{K_{b}}\left(k_{g}+D K_{f}\right), C=\frac{D}{\omega^{2}}=\frac{D K_{b}}{H^{2}\left(k_{g}+D K_{f}\right)}, \quad D=\frac{K_{s}}{K_{s}+K_{f}}
$$

式(29)と式(30b)の和を，式(31)と等值して得た，

$$
\begin{gathered}
Q_{w}(\zeta)=Q_{o}\left[\frac{k_{g}}{K_{f}}\left(1-\zeta^{2}\right)-2 A \omega \cosh (\omega \zeta)-2 B \omega \sinh (\omega \zeta)+2 C\right] \\
/\left[1+k_{g}\left(1 / K_{s}+1 / K_{f}\right)\right]
\end{gathered}
$$

と境界条件 $M_{w}(1)=0$ および

$$
\theta_{0}=\frac{M_{w}(0)}{K_{w}}+\frac{Q_{w}(0)}{K_{s}}=\frac{Q_{f}(0)}{K_{f}}=\frac{Q_{o}-Q_{w}(0)}{K_{f}}
$$




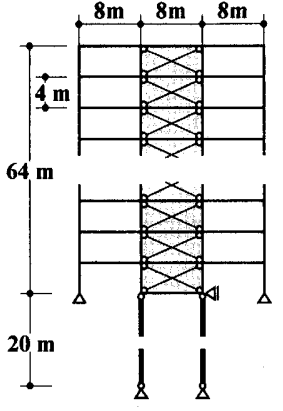

(a) 3 スパン骨組

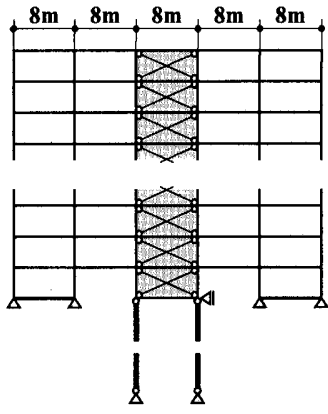

(b) 5 スパン骨組

図 12 境界梁を持つ壁体

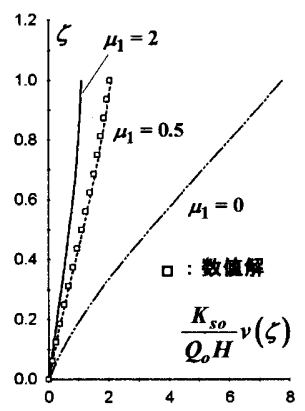

(a) 3 スパン骨組

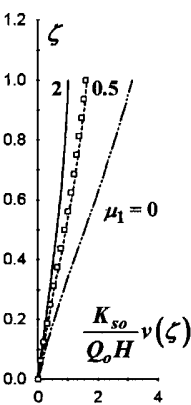

(b) 5 スパン骨組

図 13 水平変位

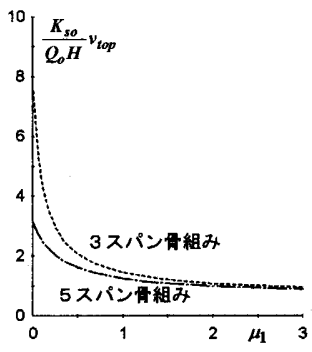

(c) 頂部変位

より積分定数 $A, B$ は次式の根として求まる.

$A \sinh (\omega)+B \cosh (\omega)=C$

$$
\begin{aligned}
& -\frac{1 / K_{s}+1 / K_{f}}{1+k_{g}\left(1 / K_{s}+1 / K_{f}\right)} \omega A+\frac{H}{K_{w}} B \\
& \quad=\frac{1}{1+k_{g}\left(1 / K_{s}+1 / K_{f}\right)}\left[\frac{1}{2 K_{f}}-C\left(\frac{1}{K_{s}}+\frac{1}{K_{f}}\right)\right]
\end{aligned}
$$

たわみ曲線は $\frac{v^{\prime}(\zeta)}{H}=\frac{1}{K_{f}}\left[Q(\zeta)-Q_{w}(\zeta)\right]$ より

$$
\begin{aligned}
v(\zeta)= & \frac{2 Q_{o} H / K_{f}}{1+k_{g}\left(1 / K_{s}+1 / K_{f}\right)}\left[\left(1+\frac{k_{g}}{K_{s}}\right) \frac{\zeta}{2}\left(1-\frac{\zeta^{2}}{3}\right)\right. \\
& +A \sinh (\omega \zeta)+B\{\cosh (\omega \zeta)-1\}-C \zeta]
\end{aligned}
$$

図 12 の鉄骨ブレース壁体を含む16 層骨組の解析結果を図 13〜16 に示す. 図 13(a),(b)は高さ方向の水平変位分布を表し, 図中の $\mu_{1}$ は 骨組部柱に対する境界梁の剛比である. $\mu_{1}=0$ は， 3 スパン骨組の 場合は図 3 の単独壁に，5 スパン骨組の場合は図 5 の単純連結系に 対応する．境界梁の存在により，頂部変位は抑制され，境界梁の剛 性が大きいと抑制効果は大きい，同図(c)は境界梁の剛性と頂部変位 の関係を示す，境界梁の剛性がある程度まで大きくなると，頂部変 位は骨組部の剛性に依存しなくなる.

ロ印で示された数値解と式(36)の対応は良好である.

図 14，15 は壁体と骨組部の水平力分担状況を示す. 図中の曲線群は 本解析結果, 折れ線は数值解析結果であり，両者の対応は良好である. 3スパン骨組では, 境界梁がない場合は単独壁体と等価となって全せ ん断力を壁体が負担するが，境界梁が存在すれば一部のせん断力が骨 組部に負担される，しかし，境界梁断面を大きくしてもその効果は小 さい，境界梁がない 5 スパン骨組は壁体と骨組部が単純連結された系 と等価となり，壁体頂部に大きな逆せん断が生じる．境界梁の存在に

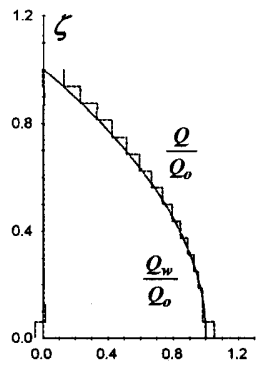

(a) $\mu_{1}=0$

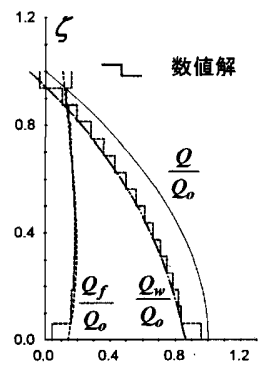

(b) $\mu_{1}=0.5$

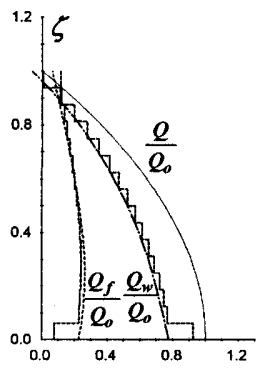

(c) $\mu_{1}=2$
図 14 水平力分担率 ( 3 スパン骨組)

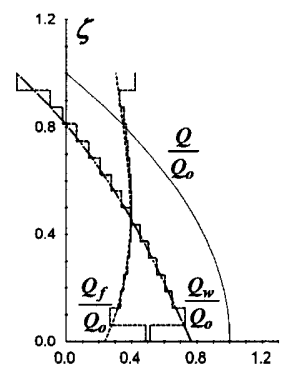

(a) $\mu_{1}=0$

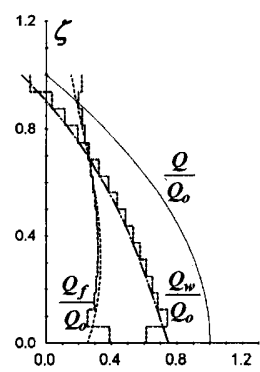

(b) $\mu_{1}=0.5$

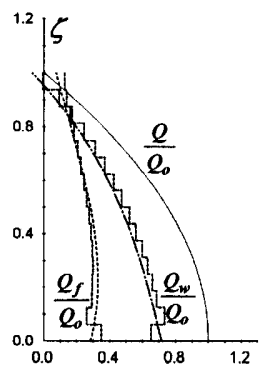

(c) $\mu_{1}=2$
図 15 水平力分担率（5 スパン骨組）

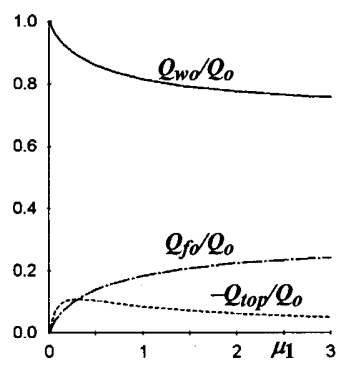

(a) 3 スパン骨組

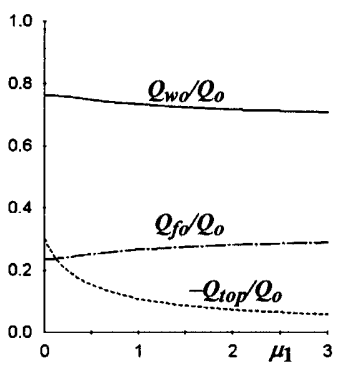

(b) 5 スパン骨組
図 16 水平力分担率と頂部逆せん断

より逆せん断は低减されるが，壁体と骨組部の水平力分担比率はほと んど変化しない．図 16 は，第 1 層での水平力分担比率および頂部逆せ ん断 $Q_{t o p}$ に及ぼす境界梁の影響を示す．3スパン骨組では，境界梁の 存在により骨組部も水平力を負担するが，それに伴って頂部逆せん断 が生じる，5スパン骨組では，境界梁断面が大きくなると頂部逆せん断 は小さくなるが，第 1 層での水平力分担比率はそれほど変化しない.

\section{6 補剛トラスを持つ壁体}

\section{1 補剛トラス単体の性状}

1) 1 区画補剛トラスの回転剛性

連層壁体の曲げ変形を抑制するには，壁体の頂部または中間に補 剛トラスを設けることが効果的である.ここでは，壁体と同一構面 内の補剛トラスのみを取り扱うが，壁体に直交する補剛トラスにつ いても同様の考察が適用できる.

図 18 に示す系では壁体脚部の曲げモーメントが補剛トラスの拘束に

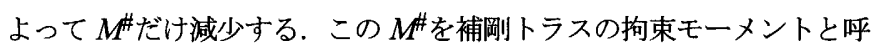
ぶ. 図の壁体脚部に $M_{t}(0)-M^{\#}$ という表示があるが，この $M_{t}(\zeta)$ $=H^{2} \int_{\zeta}^{1} q(t) t d t$ は外力による転倒モーメントである.

図 19 によれば交差部パネル（図 18 の網がけ部分）および補剛トラ 


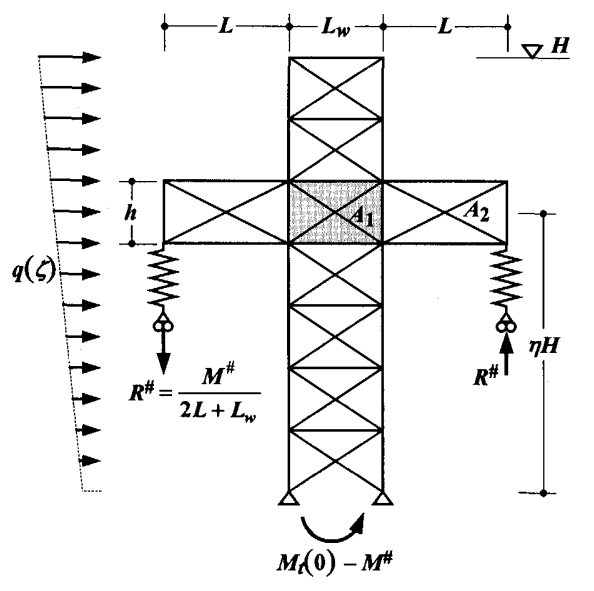

図 18 補剛トラスを持つ壁体

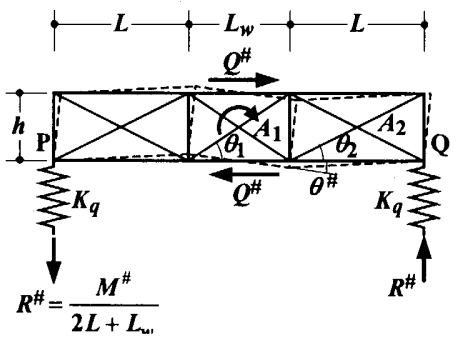

図 191 区画補剛トラスに作用寸る力と変形

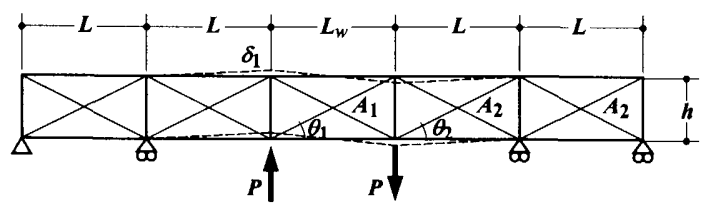

図 202 区画補㓮トラスに作用する力と変形

ス斜材の軸力 $T_{1}, T_{2}$ は次式で得られ,

$$
T_{1}=\frac{-1}{L_{w} \sin \theta_{1}}\left[\frac{M^{\#} L}{2 L+L_{w}}-\frac{Q^{\#} h}{2}\right], \quad T_{2}=\frac{1}{2 \sin \theta_{2}} \frac{M^{\#}}{2 L+L_{w}}
$$

$Q^{\#}=Q(\eta)=H \int_{\eta}^{1} q(t) d t$ は補剛トラス位置での層せん断力である.

補剛トラスおよび交差部パネルの斜材と, 支点 $\mathrm{P}, \mathrm{Q}$ の鉛直バネ (バ ネ定数 $\left.K_{q}\right)$ のみが変形すると仮定すれば，接合パネル部回転角 $\theta^{\sharp}$ は

$$
\begin{gathered}
\theta^{\#}=\frac{M^{\#}}{K_{t b}}-\frac{Q^{\#}}{K_{t s}} \\
\frac{1}{K_{t b}}=\frac{1}{K_{1}}+\frac{1}{K_{2}}+\frac{1}{K_{3}} \\
K_{1}=\frac{E A_{1} L_{w}}{2 L^{2}}\left(2 L+L_{w}\right)^{2} \sin ^{2} \theta_{1} \cos \theta_{1} \\
K_{2}=\frac{E A_{2}}{L}\left(2 L+L_{w}\right)^{2} \sin ^{2} \theta_{2} \cos \theta_{2}, K_{3}=K_{q}\left(2 L+L_{w}\right)^{2} \\
K_{t s}=\frac{E A_{1}}{L}\left(2 L+L_{w}\right) \sin \theta_{1} \cos ^{2} \theta_{1}
\end{gathered}
$$

\section{2) 交差部パネルのせん断変形}

交差部パネルには大きな逆せん断力が作用し，そのせん断変形角は

$$
\begin{aligned}
\tilde{\gamma} & =\frac{\Delta_{d} L_{1}}{h L_{w}}=\frac{T_{1}}{E A_{1} \sin \theta_{1} \cos \theta_{1}} \\
& =\frac{1}{E A_{1} L_{w} \sin ^{2} \theta_{1} \cos \theta_{1}}\left[\frac{M^{\#} L}{2 L+L_{w}}-\frac{Q^{\#} h}{2}\right]
\end{aligned}
$$

ここに $L_{1}$ および $\Delta_{d}$ は斜材の材長および伸びである.

3) 2 区画補剛トラス

図 20 の支持条件に対する 2 区画補剛トラスの回転剛性は 1 次不 静定問題の解として次式で得られる.

$$
K_{t b}=\frac{E A_{2} L_{w}^{2}}{2 L} \sin ^{2} \theta_{2} \cos \theta_{2}\left[1+\frac{\left(2+\frac{L_{w}}{2 L}\right)^{2}}{\frac{A_{2}}{A_{1}}\left(\frac{\sin \theta_{2}}{\sin \theta_{1}}\right)^{3}+\frac{1}{4}\left(\frac{L_{w}}{L}\right)^{2}}\right]
$$

4) 1 区画補剛トラスと 2 区画補剛トラス

トラス斜材に対する交差部パネル斜材の断面積比 $A_{1} / A_{2}$ を一定と し, トラス斜材断面積 $A_{2}$ を変化させた場合の回転剛性 $K_{t b}$ の比較を 図21(a)に示す. 実線は 1 区画トラスの剛性を, 一を破線で結んだ曲線 は 2 区画トラスの場合を示す. 横軸は $A_{2}$ と基準値の比, 縌軸は $K_{t b}$ と基準值の比を表し， $A_{1}=A_{2}=50 \mathrm{~cm}^{2}$ の場合を基淮状態としている. トラス斜材断面積を増すと回転剛性は比例的に増大し， $A_{1} / A_{2}$ が 大きい方が増大率は大きい，2 区画トラスは 1 区画トラスに比べて 剛性は若干大きいがその差はわずかであり，特に $A_{1} / A_{2}=1$ の場合 の両者の剛性は等しい．これは，2区画トラスであっても壁体に隣 接する区画のみが効果を発揮していることを意味する.

図 21(b)はトラス斜材断面積 $A_{2}$ を一定とし, 交差部パネル斜材の断 面積 $A_{1}$ を変化させた場合の回転剛性 $K_{t b}$ を示す. $A_{1}$ を増大させると回 転剛性も増加するが， $A_{1}$ を極端に大きくしても効果は小さい，2区画 トラスは 1 区画トラスに比べて剛性は大きいがその差はわずかである.

\section{2 高さ方向の中間に 1 区画補剛トラスを持つ壁体}

式(3)の逆三角形分布水平力を受ける壁体の断面力分布は,

$$
\begin{aligned}
& Q(\zeta)=Q_{o}\left(1-\zeta^{2}\right) \\
& M(\zeta)= \begin{cases}M_{o}\left(1-3 \zeta / 2+\zeta^{3} / 2\right)-M^{\#} & \zeta<\eta \\
M_{o}\left(1-3 \zeta / 2+\zeta^{3} / 2\right) & \zeta>\eta\end{cases}
\end{aligned}
$$

$\eta=H^{\prime} / H, \quad H^{\prime}$ : 補剛卜ラス位置, $M^{\#}$ : 拘束モーメント 変形状態は，外力のみによるたわみとして

・ 世九断変形 $\frac{v_{s}^{\prime}(\zeta)}{H}=\frac{Q_{o}}{K_{s}}\left(1-\zeta^{2}\right)$

- 曲げ変形 $\quad \frac{v_{b 1}^{\prime}(\zeta)}{H}=\frac{M_{o} H}{K_{b}} \zeta\left(1-\frac{3}{4} \zeta+\frac{1}{8} \zeta^{3}\right)+\theta_{o}$

$$
\theta_{o}=\left(M_{o}-M^{\#}\right) / K_{w}
$$

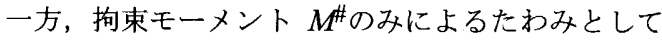

- 曲げ変形 $\frac{v_{b 2}^{\prime}(\zeta)}{H}=-\frac{M^{\#} H}{K_{b}} \cdot \begin{cases}\zeta & \zeta<\eta \\ \eta & \zeta>\eta\end{cases}$

次式による境界条件

$$
\begin{aligned}
\theta^{\#} & =\frac{M^{\#}}{K_{t b}}-\frac{Q_{o}}{K_{t s}}\left(1-\eta^{2}\right) \\
& =\frac{v_{b}^{\prime}(\eta)}{H}=\frac{M_{o} H}{K_{b}} \eta\left(1-\frac{3}{4} \eta+\frac{1}{8} \eta^{3}\right)-\frac{M^{\#} H}{K_{b}} \eta+\frac{M_{o}-M^{\#}}{K_{w}}
\end{aligned}
$$

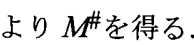

$$
\begin{gathered}
M^{\#}=M_{o}\left[\frac{1}{K_{w}}+\frac{H}{K_{b}} \eta\left(1-\frac{3}{4} \eta+\frac{1}{8} \eta^{3}\right)+\frac{3}{2 K_{t s} H}\left(1-\eta^{2}\right)\right] \\
/\left(\frac{H}{K_{b}} \eta+\frac{1}{K_{t b}}+\frac{1}{K_{w}}\right)
\end{gathered}
$$


たわみ関数は式(39)による接合パネル部の変形 $\gamma h$ を考虑して

$$
\begin{aligned}
v(\zeta)=\frac{Q_{o} H}{K_{s}}\left[\zeta\left(1-\frac{1}{3} \zeta^{2}\right)+\frac{1}{6 \beta_{w}} \zeta^{2}\left(2-\zeta+\frac{1}{10} \zeta^{3}\right)+\frac{2}{3 k_{w}} \zeta\right] & -\frac{M^{\#}}{k_{w} K_{s}} \zeta-f(\zeta) \\
f(\zeta)= & \begin{cases}\frac{M^{\#}}{2 \beta_{w} K_{s}} \zeta^{2} & \zeta<\eta \\
\frac{M^{\#}}{\beta_{w} K_{s}} \eta\left(\zeta-\frac{\eta}{2}\right)+\gamma h & \zeta>\eta\end{cases}
\end{aligned}
$$

頂部に補剛トラスを持つ壁体の変形モードを図 22 に示す．同図(a) 中の $A_{2} / A_{b}$ は補剛トラス斜材と壁体筋違の剛性比を表し, $A_{2}=0$ は補 剛トラスがない場合に相当する. 補剛トラスの存在によって頂部変位 は著しく低減されるが，補剛トラスの剛性を極端に増大させてもその 効果は小さい. 印は $A_{2} / A_{b}=1$ に対する数值解であり, 式(34)との 対応はよい. 同図(b) は壁体脚部回転岡性の影響を示す， $k_{w}=0.7$ お よび 0.23 はそれぞれ壁体脚部が $20 \mathrm{~m}, 60 \mathrm{~m}$ の現場打杭で支持された 状態に相当し, 脚部転剛性は壁体の変形に大きな影響を与える.

図 23 は建物高さの中央付近に補剛トラスを設けた場合の補剛トラ 不剛性と変形の関係を示す. 図 22(a)と同様の傾向を示すが, 頂部の 変位は図 22 より小さい.

図 24 は補剛トラス位置と頂部変位の関係を示し，図中の $\beta_{w}$ は壁体 の側柱と筋違の断面積比に比例する量である. 補剛トラスの機能が主 として壁体の曲げ変形の抑制にあり, 壁体曲げ剛性が小さいほどその 影響が大きいことがわかる，壁体頂部変位は，補剛トラスが建物高さ の 6 割程度の位置にある場合に最小となる.

\section{7 結 論}

1) 連層壁体を曲げせん断棒に直換し，連層壁体を含む骨組の変形性 状に関する解析解を得た。表計算ソフト程度の解析ツールにより大 型構造物の挙動を巨視的にとらえることができる.

2) 得られた解は数值解と良好な対応を示寸.

3) 連層壁体と純骨組が単純連結された骨組では, 最上層床レベルで 壁体と骨組の間に大きな集中力が作用する.

4) 境界梁の存在は壁体の曲げ変形を著しく抑制するが，境界梁剛性 をいたずらに大きくしても効果は小さい.

5) 中間に補剛トラスを持つ壁体では, 補剛トラスの存在は壁体変形を 著しく抑制するが，トラスの岡性を極端に大きくしても効果は小さい. 6) 補剛トラスは建物高さの 6 割程度の位置に設けるのが効果的である.

\section{参考文献}

1) 堀井昌博・和田 章: 耐震壁に生じる逆せん断力一構造設計のためのメモ ランダム 1 ，建築技術 No.341，pp.107-110，1980.01

2) 堀井昌博・和田 章: 耐震壁のモデル化の方法とその比較一構造設計のた めのメモランダム 5 , 建築技術 No.347, pp.131-136, 1980.07

3) 堀井昌博・和田 章: ラーメン架構の変形特性とその要因一構造設計の ためのメモランダム 6 ，建築技術 No.348, pp.159-173， 1980.08

4) 藤井大地・藤谷義信 : 薄肉はり理論にもとづく立体高層骨組の有限要素法 解析一薄肉はり置換法による高層ビルの構造解析に関寸る研究 (その 1 ), 日本建築学会構造系論文報告集, No.453, pp.65-75, 1993.11.

5) 藤井大地・藤谷義信 : 薄肉はり置換法の実務設計一の適用に関する検討 一薄肉はり置換法による高層ビルの構造解析に関する研究 (その 2$)$, 日 本建築学会構造系論文集, No.467, pp.45-53, 1995.01.

6) 藤井大地・藤谷義信 : 薄肉はり置換法による高層ビルの最適設計一薄肉は り置換法による高層ビルの構造解析に関する研究 (その 3 ), 日本建築学

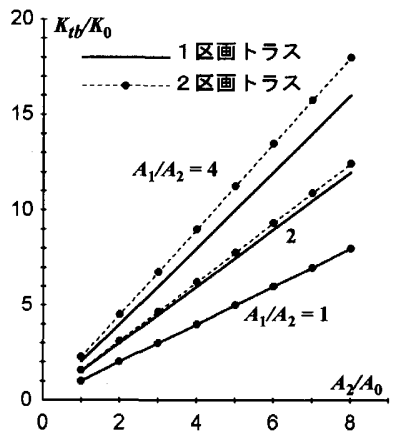

(a) トラス斜材の効果

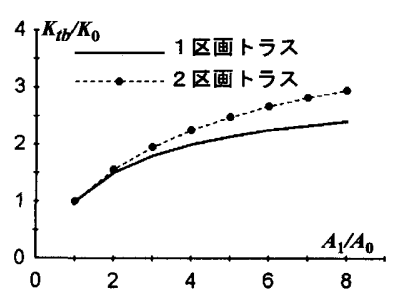

(b) 交差部パネル斜材の効果
図 21 補剛トラスの回転剛性

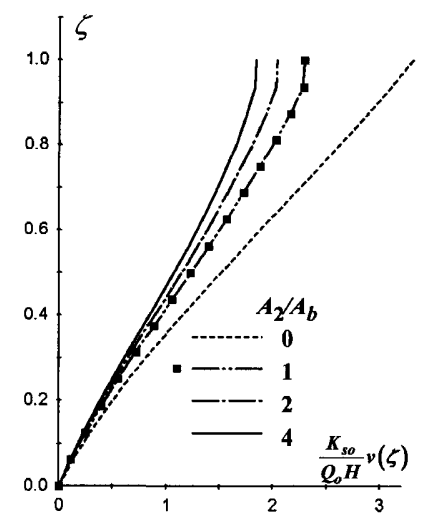

(a) トラス剛性の影響

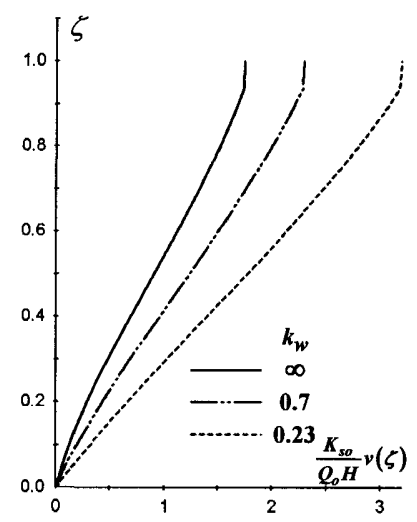

(b) 杭剛性の影響
図 22 頂部トラスを持つ壁体の変形

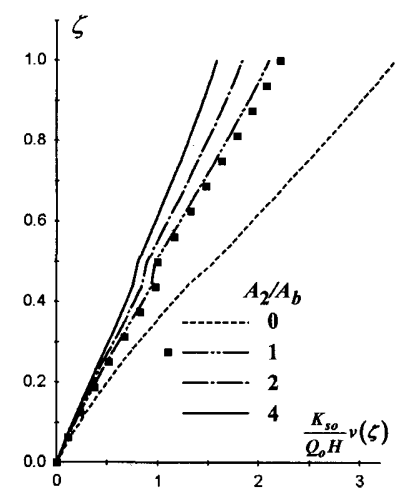

図 23 中間トラスを持つ壁体

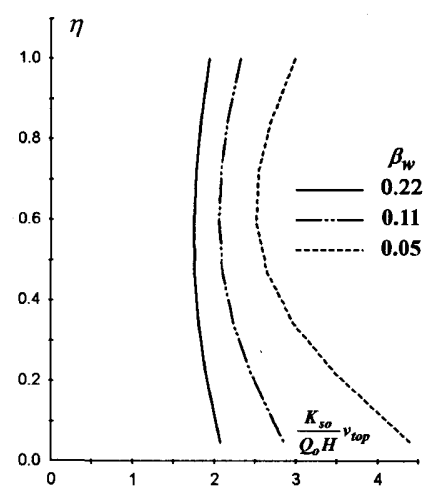

図 24 補剛位置と頂部変位
会構造系論文集, No.477, pp.57-66，1995.11.

7) Beck, H. : Contribution to the Analysis of Coupled Shear Wall, ACI Journal, Vol.59, No.8, pp.1055-1069, 1962.08.

8) Rosman, R. : Approximate Analysis of Shear Walls Subjected to Lateral Loads, ACI Journal, Vol.61, No.6, pp.717-733, 1964.06.

9) Tso, W. K. and Chan, H : Dynamic analysis of Plane Coupled Shear Walls, Proc.ASCE, Vol.97, EM1, pp.33-48, 1971.

10) 大沢 胖: 耐震コア一式高層建物の動的特性, 日本建築学会論文報告集, No.102, pp.1-9, 1964.09.

11) 大沢 胖・洪 忠喜: 耐震コアー式高層骨組の弾塑性計算法, 日本建築学 会論文報告集, No.101, pp.23-30, 1964.08.

12) 益尾潔·安部 勇·秦 雅史: RC 層而震壁架構の弾塑性変形性状に関する解析 的研究 (その1 解析法), 日本建築学会論文報告集, No.339, pp.1-9, 1984.05.

13）日置興一郎・山中邦一・北野博己 : 反り変形を考えた棒理碖による高層架構の 解析 その 1. 弾性静力学, 日本建筮学会論文報告集, No253, pp.51-57, 1977.03. 